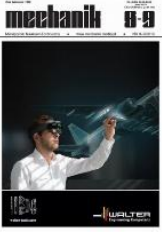

Authors: Jan Burek, Tomasz Rydzak, Artur Szajna

Title of article: „Wpływ zmiany orientacji osi narzędzia oraz kierunku jego prowadzenia w obróbce powierzchni swobodnej na chropowatość powierzchni" ("The influence of the tool axis orientation changes and the direction of tool driving in free surface machining on surface roughness")

Mechanik, Vol. 91, No. 8-9 (2018): pages 684-686

DOI: https://doi.org/10.17814/mechanik.2018.8-9.107

\title{
The influence of the tool axis orientation changes and the direction of tool driving in free surface machining on surface roughness
}

\author{
Wpływ zmiany orientacji osi narzędzia oraz kierunku jego prowadzenia \\ w obróbce powierzchni swobodnej na chropowatość powierzchni
}

\section{JAN BUREK \\ TOMASZ RYDZAK \\ ARTUR SZAJNA *}

Presented is the effect of the direction of tool driving along parametric curves from a free surface and changes of the tool axis orientation on roughness parameters during finishing machining.

KEYWORDS: free surface machining, tool orientation, simultaneous machining

The machining of complex surfaces is still the subject of research. Complex geometries are most often created on the basis of parametric curves with a high degree of curvature and its changeable character as well as unstretched free surfaces. The 3D or 5D milling technology applied so far allows to meet the high demands placed on shaping curved free surfaces to varying degrees. Performing multi-axis machining cycles on machine tools with extensive kinematics is supported by advanced CAM systems.

The correctness of the NC code generated in these systems, describing the trajectory of the tool movement relative to the workpiece free surface, depends primarily on the orientation of the tool axis in the work space [1]. In addition to technological and geometric parameters, the strategy of guiding the tool relative to the surface to be machined and the tool orientation may affect the surface quality and accuracy of the work piece [2]

Initial tests of the impact assessment of the change of the axis orientation of the spherical mill were carried out depending on the direction of the tool during the finishing machining on the roughness of the free surface.

\section{Multi-axis milling of free surfaces}

Advanced CAM systems use various methods and algorithms to implement the path shape of the tool motion path relative to the main curves of the work surface $[3,4]$.

\footnotetext{
* Dr hab. inż. Jan Burek prof. PRz (jburek@prz.edu.pl), mgr inż. Tomasz Rydzak (t.rydzak@prz.edu.pl), mgr inż. Artur Szajna (a.szajna@prz.edu.pl) - Katedra Technik Wytwarzania i Automatyzacji, Wydział Budowy Maszyn i Lotnictwa Politechniki Rzeszowskiej
}

One of them is based on the adaptive strategy of positioning the tool axis relative to the defined normal vectors at selected points on the complex surface (fig. 1) [5].

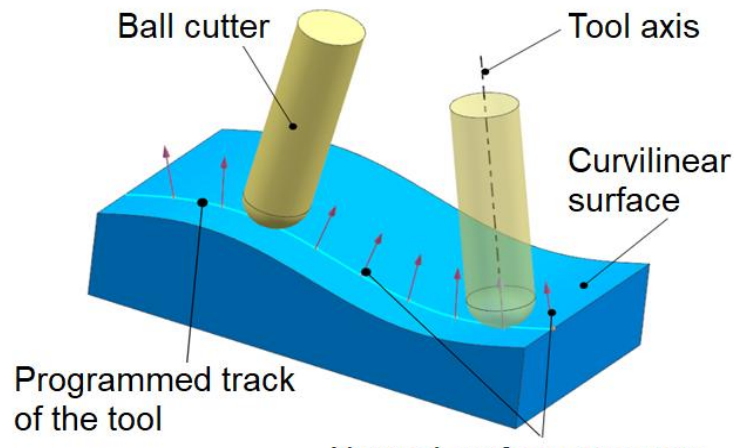

Normal surface $\bar{n}$ vectors defined at selected points

Fig. 1. Positioning the tool axis relative to defined normal vectors at selected points on the complex surface

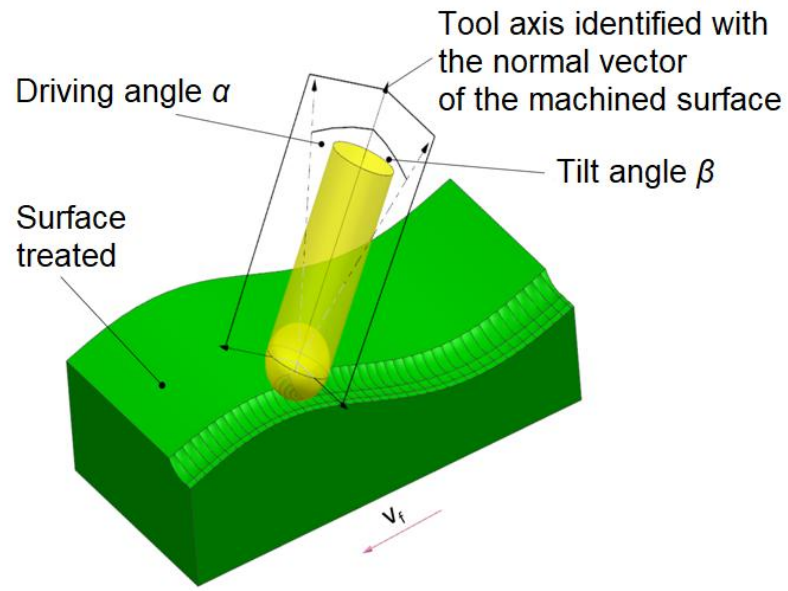

Fig. 2. Tool orientation with respect to the normal vector $\bar{n}: \alpha-$ lead angle, $\beta$ - tilt angle, $v_{f}-$ feed speed 
The lead angles $\alpha$ are defined relative to the normal vector, in the feed direction, while the tilt angle $\beta$ perpendicular to the feed direction (fig. 2).

Determination of these two angles with respect to the normal vector of the considered surface allows to clearly determine the position of the cutting tool's axis in the working space of the machine tool.

\section{Test conditions}

The tests were carried out on the test part, on which the geometry was created based on two parametric curves, described by the sine function in both main directions, differing in amplitude and period. A free surface, characterized by different Gaussian curvatures, has been spanned on these curves (fig. 3).

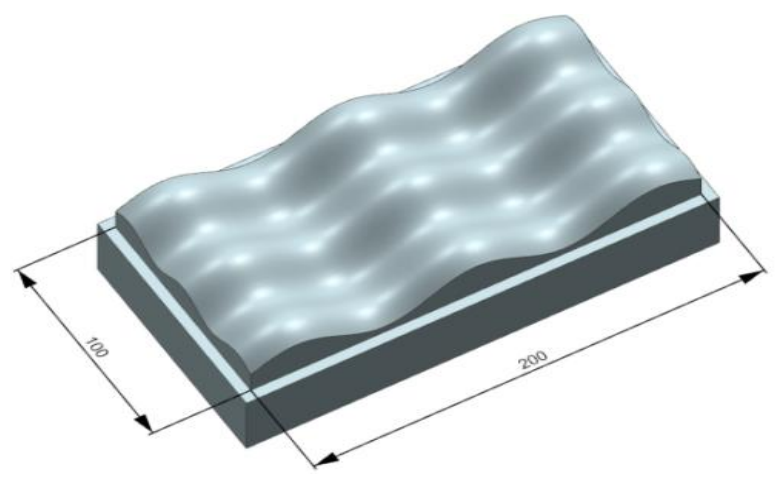

Fig. 3. 3D-CAD model of the test part

The surface machining was carried out on a DMU 100 monoBLOCK multiaxial milling center with the Sinumerik 840D control system (fig. 4).

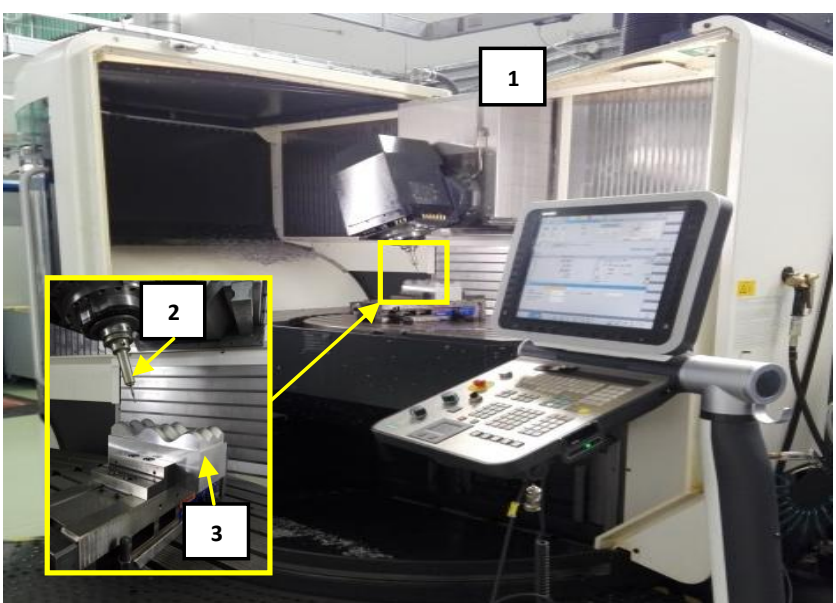

Fig. 4. Test stand: 1 - five-axis machining center DMG 100 monoBLOCK, 2 - tool, 3 - test part

The machining program was developed in the NX CAM system. The tests were carried out on three samples, depending on the change of the tilt angle $\beta$ or lead angle $\alpha$, direction of the tool and the effective cutting speed. A R216.42-05030-AK10A spherical cutter was used for machining and an EN-AW 7075 aluminum alloy was machined.

The surface of the first sample was divided into two equal zones. In one zone, the tool was guided along the short edge of the model, while in the other - along the long edge. The tool axis was positioned relative to local normal vectors, specifying angles $\alpha=0$ and $\beta=0$, respectively (fig. 5).

The surfaces of the second and third samples were divided into four zones. In selected zones, the lead angle $\alpha$ or the tilt angle $\beta$ relative to the defined normal vectors and the effective cutting speed were changed depending on the value of these angles, by changing the spindle speed $[2,6]$ (fig. 6).

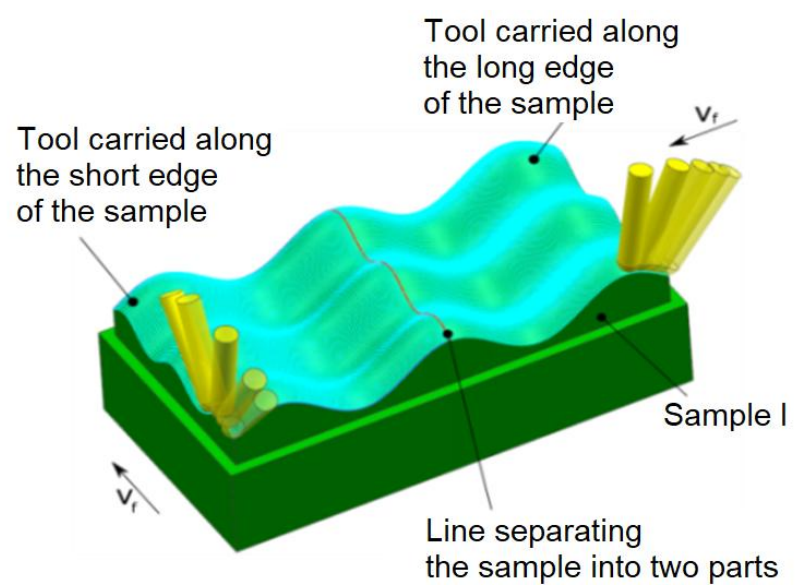

Fig. 5. Visualization of tool movement paths - the first sample

a)

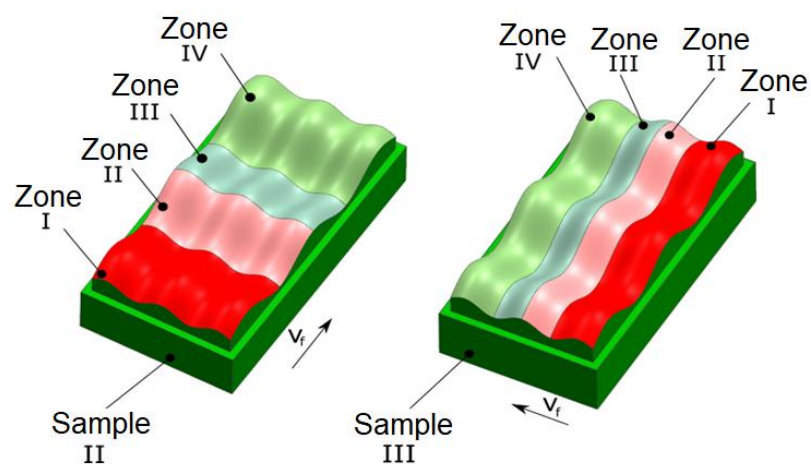

b)

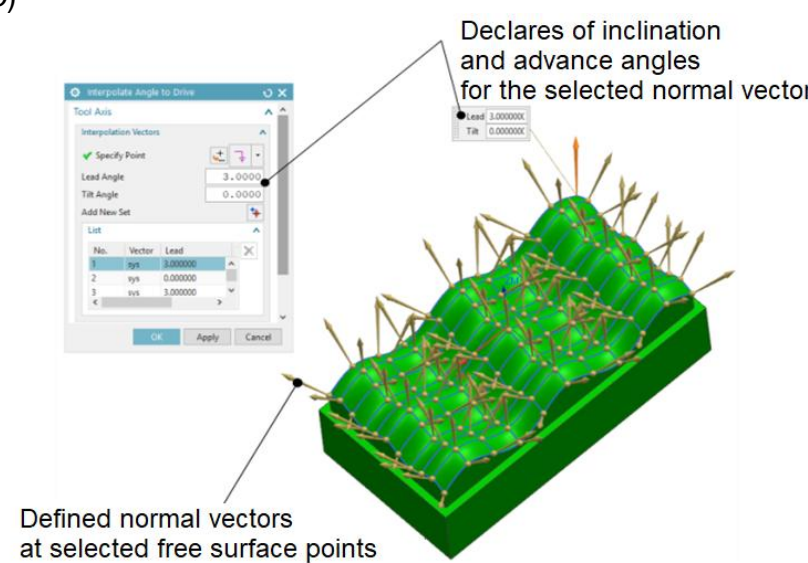

Fig. 6. Test parts: a) tool angle change zones for the second and third samples, $b$ ) values of the tool axis angles relative to the defined normal vectors

TABLE. Cutting parameters and tool axis orientation

\begin{tabular}{|c|c|c|c|c|c|}
\hline \multicolumn{2}{|c|}{ Parameters } & $n, \mathrm{rpm}$ & $\begin{array}{c}V_{\mathrm{c}} \\
\mathrm{m} / \mathrm{min}\end{array}$ & $\alpha,^{\circ}$ & $\beta,{ }^{\circ}$ \\
\hline \multicolumn{2}{|c|}{ Sample I } & 18000 & 235 & 0 & 0 \\
\hline \multirow{4}{*}{$\underset{I I}{\text { Sample }}$} & Zone I & 16796 & 235 & 3 & 0 \\
\hline & Zone II & 13324 & 235 & 15 & 0 \\
\hline & Zone III & 16796 & 235 & 0 & 3 \\
\hline & Zone IV & 13324 & 235 & 0 & 15 \\
\hline \multirow{4}{*}{$\begin{array}{c}\text { Sample } \\
\text { III }\end{array}$} & Zone I & 16796 & 235 & 3 & 0 \\
\hline & Zone II & 13324 & 235 & 15 & 0 \\
\hline & Zone III & 16796 & 235 & 0 & 3 \\
\hline & Zone IV & 13324 & 235 & 0 & 15 \\
\hline
\end{tabular}


The same geometrical parameters were assumed for each sample: $a_{\mathrm{p}}=0.2 \mathrm{~mm}, a_{\mathrm{e}}=0.5 \mathrm{~mm}$ and feed per tooth $f_{z}=0.028 \mathrm{~mm} /$ tooth. In order to maintain a constant cutting speed when changing the orientation of the tool axis, the rotational speed (table) is defined accordingly.

\section{Analysis and research results}

A MarSurf GD 120 profiler from Mahr was used to determine the roughness of the machined surfaces. Ra and $R z$ roughness parameters were measured. The obtained values are shown in figs. 7-10.

Results of the roughness measurements indicate that the change of the angles of tilt and lead of the tool axis significantly affects the roughness parameters $R a$ and $R z$ measured perpendicular to the direction of feed. For the surface treated along the long and short edges, this improvement was in the order of $30 \%$ - Ra parameter (fig. 7) and 20\% - Rz parameter (fig. 9).

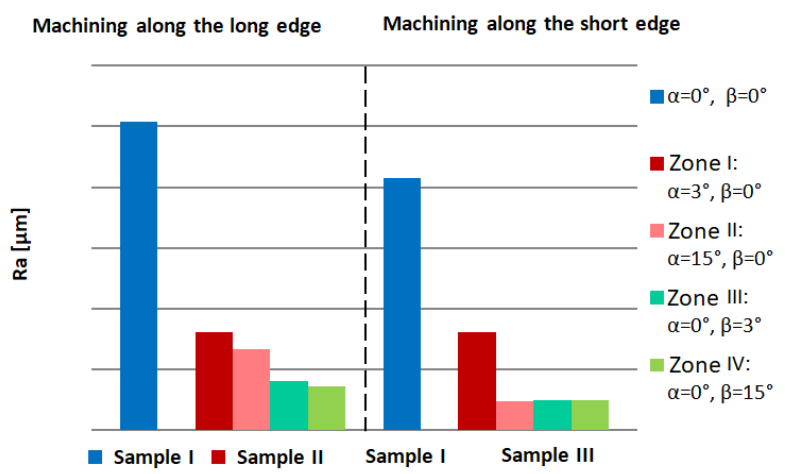

Fig. 7. Ra parameter measured transverse to the feed

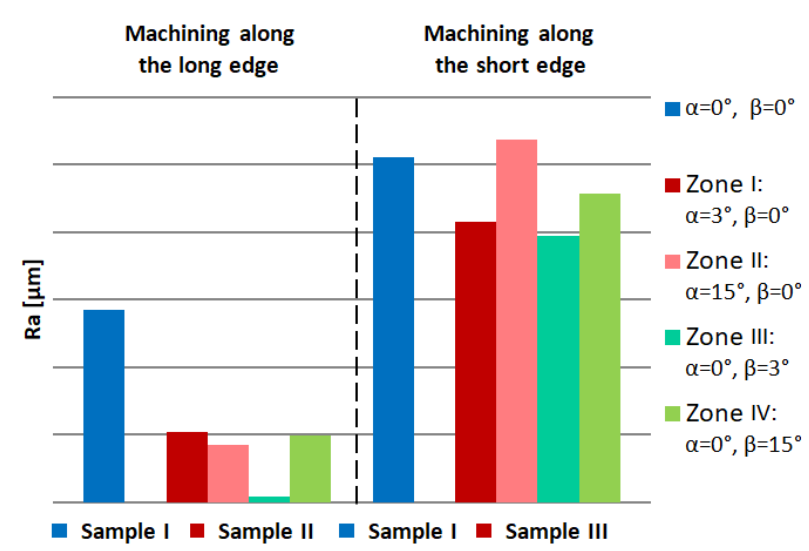

Fig. 8. Ra parameter measured longitudinally to the feed

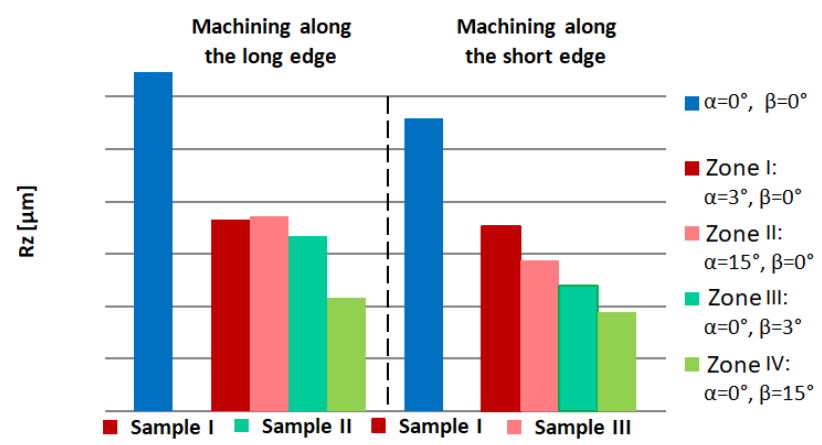

Fig. 9. $R z$ parameter measured transverse to the feed

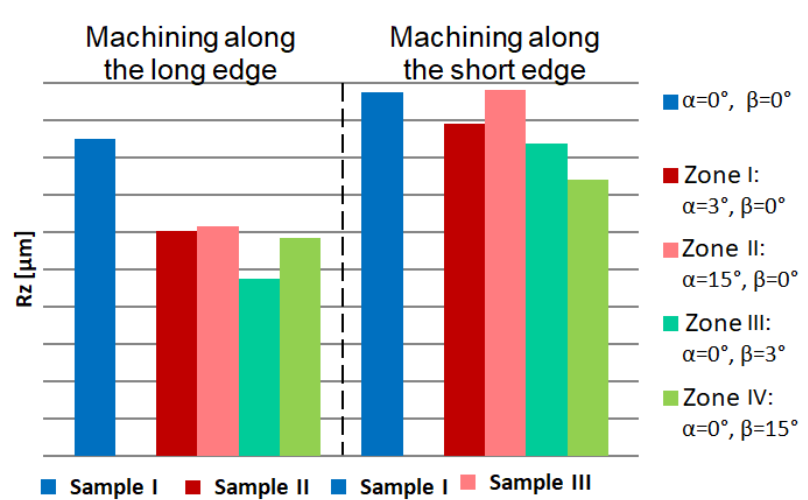

Fig. 10. $R z$ parameter measured longitudinally to the feed

For measurements parallel to feed, better results were obtained for the surface treated along the long edge. For this area, the reduction of the $R a$ parameter was on the order of $26 \%$ (fig. 8), and the parameter $R z-$ around $30 \%$ (fig. 10). It cannot be unambiguously determined whether the direction of the tool in the finishing process influenced the results due to the insufficient difference in the values of $R a$ and $R z$ parameters in the tool directions studied. The smallest values of the roughness parameters $R a$ and $R z$ were obtained for the defined tilt angles $\beta$.

\section{Conclusions}

The presented analysis shows that in the process of simultaneous milling of a five-axis composite surface, the change in the orientation of the tool axis relative to the normal vector, through lead and tilt angles, affects the surface roughness. Appropriate selection of these angles, even at small ranges of their value, allows to achieve a definite improvement in the quality of the surface being treated.

\section{REFERENCES}

1. Burek J., Żyłka Ł., Gdula M., Płodzień M. „Wpływ kinematyki 5osiowego frezowania na chropowatość powierzchni pióra łopatki”. Mechanik. 87, 8 (2014): pp. 437-444.

2. Mikó Balázs, Beňo Jozef. „Effect of the working diameter to the surface quality in free-form surface milling”. Key Engineering Materials. 581 (online: $7^{\text {th }}$ October 2013): pp. 372-377.

3. Qiang Zoua, Juyong Zhanga, Bailin Dengb, Jibin Zhaoc. „Isolevel tool path planning for free-form surfaces". Computer-Aided Design. 53 (2014): pp. 117-125.

4. Warkentina Andrew, Ismailb Fathy, Bedib Sanjeev. "Comparison between multi-point and other 5-axis tool positioning strate gies". International Journal of Machine Tools \& Manufacture. 40 (2000): pp. 185-208.

5. Burek J., Gdula M., Sułkowicz P., Żurek P. „Strategia 5-osiowej obróbki łopatek turbin uwzględniająca zmiany krzywizny obrabianego profilu". Mechanik. 12 (2016): pp. 1892-1893.

6 . Burek J., Żurek P., Żurawski K. „Wpływ kąta pochylenia na chropowatość powierzchni złożonych po obróbce frezem kulistym". Mechanik. 10 (2016): pp. 1478-1479.

Translation of scientific articles, their computer composition and publishing them on the website www.mechanik.media.pl by original articles in Polish is a task financed from the funds of the Ministry of Science and Higher Education designated for dissemination of science.

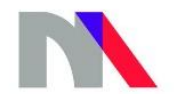

Ministry of Science and Higher Education

Republic of Poland 